\title{
Temporal variations of ecological security with soil and water loss stress in black soil region of northeast China: a case study on Baiquan County
}

\author{
Liying Sun ${ }^{1}$, Zhenju Liư ${ }^{2}$ Mingguo Zheng ${ }^{1}$, Qiangguo Cai ${ }^{*}$, Haiyan Fang ${ }^{1}$ \\ From 2010 International Conference on Combating Land Degradation in Agricultural Areas (ICCLD'10) \\ Zi'An City, PR China. 11-15 October 2010
}

\begin{abstract}
The deterioration of ecological situation with serious soil and water loss in black soil region of northeast China has attracted more attention due to its significant role on food security of China. To investigate the temporal characteristics of ecological status in typical black soil areas, Baiquan County is selected. Based on the model of Press-Status-Response (P-S-R), indicators are established and the ecological security situations with soil and water loss of Baiquan County are evaluated for the years of 1979, 1990, 2000 and 2005. The results show that the ecological insecurity indicator changes from 0.701 to 0.435 from 1979 to 2005, with a decrease of 37.9\% for Baiquan County. And the contributions of physical and human factors to the temporal variations of the ecological security are discussed in detail. Moreover, several problems are recognized to be the potential threats to the ecological security in Baiquan county, including reduction of the effective thickness, excessive application of the fertilizer and low efficiency of the agricultural irrigation system. It is found that effective soil and water loss control actions have made great contribution to the improvement of the ecological security in Baiquan county. All these results and discussions are very helpful for the further investigation on the quantitative relationship between soil and water loss and ecological security in black soil region of northeast China.
\end{abstract}

\section{Introduction}

The concept of ecological security has been widely considered after it was proposed by the government of the United States [1]. Generally, the broad-sense conception of ecological security includes the complex systems of natural, economic and social system, while the narrow-sense conception of ecological security focused on the natural and human influenced ecosystems [2,3]. As the significant role of the ecological security on the sustainable development, how to establish scientific evaluation methods to measure different levels of the ecological security is key aspect of the related studies [4]. However, there is no agreement on the universally accepted definition, nor the standard assessment approaches [3].

\footnotetext{
* Correspondence: caiqg@igsnrr.ac.cn

${ }^{1}$ Key Laboratory of Water Cycle and Related Surface Processes, Institute of Geographical Sciences and Resources Research, Chinese Academy of

Sciences, Beijing 100101, China

Full list of author information is available at the end of the article
}

Different assessment approaches and models, such as ecological foot print method, Press-Status-Response (P-S-R) model, cellular automata model and security patterns and surface model, are proposed for various ecosystems and requirements of different time-space dimensions [3,5-7]. P-S-R framework model could illustrate the causality between the driving pressures and their results, and potential influencing factors could be found through the analysis of the assessment results [8]. Thus, comprehensive evaluation method based on P-S-R framework model is used in this paper.

Black soil region of Northeast China, one of the three typical black soil regions in the world, performs significant roles on the crop production and food security in China [9]. However, serious soil and water loss has caused the degradation of the ecological system due to unreasonable human cultivation and the special physical background of the local region [10]. Efficient soil and water control actions have been taken since 1980s. The major purpose

\section{SpringerOpen $^{\circ}$}

(C) 2013 Sun et al; licensee Springer This is an open access article distributed under the terms of the Creative Commons Attribution License (http://creativecommons.org/licenses/by/2.0), which permits unrestricted use, distribution, and reproduction in any medium, provided the original work is properly cited. 
of this paper is to investigate the temporal variations of ecological security with soil and water loss stress in black soil region of Northeast China during the period of 1979 to 2005. Potential problems to the ecological security and effects of soil and water control on the changes of the ecological security were discussed for the further actions to protect the valuable black soil resources.

\section{Study area and evaluation method Study area}

Baiquan county is located at $125^{\circ} 30^{\prime} \mathrm{E} \sim 126^{\circ} 31^{\prime} \mathrm{E}$ and $47^{\circ} 20^{\prime} \mathrm{N} \sim 47^{\circ} 55^{\prime} \mathrm{N}$, where is the hinterland of typical black soil zone in Northeast China with a population of approximately 0.55 million inhabitants. The total land area of Baiquan county is about 0.36 million $\mathrm{hm}^{2}$. The altitude of Baiquan county is from $240 \mathrm{~m}$ to $280 \mathrm{~m}$. Rolling hill regions are taking approximately $77 \%$ of the county's total land area, characterized by long slopes of the ramp. The majority of slope lengths in rolling hill regions are from $300 \mathrm{~m}$ to $500 \mathrm{~m}$, and it could be up to be more than $1 \mathrm{~km}$.

The total water resources of Baiquan county is 0.47 billion $\mathrm{m}^{3}$ and the average annual runoff depth is $45.97 \mathrm{~mm}$ with the annual precipitation of $490 \mathrm{~mm}$. Although the precipitation is not high, the special topographic conditions, such as the long slopes could increase the runoff yield and concentration area, and unreasonable human activities have made serious soil erosion in rolling hill regions of the county. Up to now, soil erosion area is about 0.21 million $\mathrm{hm}^{2}$, accounting for about $58 \%$ of the county's total land area. In which, most soil loss happened in cultivated land, achieving 0.17 million $\mathrm{hm}^{2}$ and accounting for about $68 \%$ of the total cultivated land area in Baiquan county. On the other side, considerable attention has been focused on soil and water conservation and a series of demonstration projects have been implemented in Baiquan County since 1980s.

\section{Comprehensive evaluation method}

Based on the pressure-state-response (P-S-R) framework model, comprehensive evaluation method is used for the assessment of the ecological security of Baiquan county. Firstly, a four-layer index system is established according to the basic principles, such as representativeness, integrity, stability and availability. Secondly, Weights are determined for each index using the analytic hierarchy process (AHP) method. After that, specific data for four years, 1979, 1990, 2000 and 2005, are collected for the indices in the basic layer of the evaluation index system. Thus the evaluation results could reflect the temporal variations of ecological security with soil and water loss stress in Baiquan county.

\section{Evaluation indices}

In fact, to establish evaluation indices for the assessment of ecological security is a kind of complicated work, due to the complexity of the ecosystem in different scales and for different concerns. In this paper, the assessment focused on safety of the ecological system with soil and water loss stress in the local scale of Baiquan county. Based on the spirit of the (P-S-R) framework, a fourlayer index system with 16 basic indices is established (Table 1). The topmost layer of the index system is a negative index to reflect the ecological security, which means the ecological situation is worsen when the calculated values of this index is higher. Thus it named the 'Ecological Unsafety Index'. Representative factors related to the soil and water loss are selected for the 'pressure', 'status' and 'response' indices, including natural and human factors that influencing the ecological security.

\section{Weight determination}

The Analytic Hierarchy Process (AHP) is a structured technique that was developed in the 1970s and has been extensively studied and modified after then [11,12]. To deal with complex decisions, AHP provides a comprehensive and rational framework. AHP is trying to find a solution that best suits the needs of the decision makers according to their understanding and attitude to the problem. Normally, the AHP includes five steps [12]: (1) decomposing the decision problem into a hierarchy of simpler sub-problems, usually a hierarchy of evaluation indices is established; (2) Building pair-wise comparison matrix in different levels to judge the importance of the elements by paired comparison using the scale method [1,9]; (3) Determining the relative weight of one element to another through calculating the priority vector and maximum eigenvalue of the comparison matrix; (4) Examination the consistency of the pair-wise comparison matrix in different levels by calculating the consistency index $(C I)$ for each level of the hierarchy structures; (5) Calculation the relative weight of the each element to the whole target and examination the consistency of the whole hierarchical matrix. Herein, the process of the weight determining has been programmed using Matlab Soft (Version 7.0). The calculated weights for each index to the 'Ecological Unsafety Index' in the topmost layer of the evaluation indices are listed in Table 1.

\section{Data collection and processing}

Data for each basic index are collected mainly from the statistical documents published by the local government and related investigations in Baiquan county. The purpose of this article is mainly focused on the temporal variations of ecological security from 1970s to the present. However, the year-to-year data are not available for all indices during this period of time. Thus, according to the availability of the data sources, four years are especially investigated in this article. They are 1979, 1990, 2000 and 2005. As effective soil and water loss control actions were began from 1980s, situations in 1979 are obviously 
Table 1 Evaluation indices for ecological security of Baiquan County

\begin{tabular}{|c|c|c|c|c|}
\hline $1^{\text {st }}$ layer & $2^{\text {nd }}$ layer & $3^{\text {rd }}$ layer & $4^{\text {th }}$ layer & Weight \\
\hline \multirow[t]{13}{*}{$\begin{array}{l}\text { Ecological Unsafety Index } \\
\text { (A) }\end{array}$} & $\begin{array}{l}\text { Pressure } \\
\left(B_{1}\right)\end{array}$ & Population Pressure $\left(C_{1}\right)$ & Natural Population Growth Rate $\left(D_{1}\right)$ & 0.0174 \\
\hline & & & Population Density $\left(D_{2}\right)$ & 0.0174 \\
\hline & & Land Pressure $\left(C_{2}\right)$ & Per Capita Arable Land $\left(D_{3}\right)$ & 0.0423 \\
\hline & & & Area Proportion of Soil and water Loss $\left(D_{4}\right)$ & 0.1395 \\
\hline & & Pollution Pressure $\left(C_{3}\right)$ & Fertilizer Load $\left(D_{5}\right)$ & 0.0397 \\
\hline & & & Pesticide Load $\left(D_{6}\right)$ & 0.0397 \\
\hline & $\begin{array}{l}\text { Status } \\
\left(B_{2}\right)\end{array}$ & Environmental Status $\left(C_{4}\right)$ & Probability of Natural Disaster $\left(D_{7}\right)$ & 0.0749 \\
\hline & & & Forestry and Grass Coverage $\left(D_{8}\right)$ & 0.0943 \\
\hline & & & Soil Erosion Modulus $\left(D_{9}\right)$ & 0.1188 \\
\hline & & Natural Resources Status $\left(C_{5}\right)$ & Effective Thickness of Soil Layer $\left(D_{10}\right)$ & 0.1113 \\
\hline & & & Precipitation Rate of April May to July August $\left(D_{11}\right)$ & 0.0701 \\
\hline & $\begin{array}{l}\text { Response } \\
\left(B_{3}\right)\end{array}$ & Social Response $\left(C_{6}\right)$ & Effective Irrigation Rate of Arable Land $\left(D_{12}\right)$ & 0.0394 \\
\hline & & $\begin{array}{l}\text { Environmental Response } \\
\left(C_{7}\right)\end{array}$ & $\begin{array}{l}\text { Agricultural Technican Numbers Per Ten Thousand People } \\
\left(D_{13}\right)\end{array}$ & 0.0156 \\
\hline \multirow[t]{3}{*}{1} & & Economic Response $\left(C_{8}\right)$ & Area Proportion of Soil and Water Loss Control $\left(D_{14}\right)$ & 0.1102 \\
\hline & & & Per Capita Rural Net Income $\left(D_{15}\right)$ & 0.0347 \\
\hline & & & Agriculture Production Per Unit Cultivated Land $\left(D_{16}\right)$ & 0.0347 \\
\hline
\end{tabular}

different from those years after 1986. To some extent, this increases the comparability of the investigation results.

Data standardization is necessary to avoid the incomparability of the data for different indices due to their different dimensional units. Single threshold method is used for the data standardization in this article. For positive indices, data standardization is carried out according to formula (1), while it is carried out according to formula (2) for the negative indices. Through the standardization process, the standardized values are in the range of $0[1]$. As the topmost index is 'Ecological Unsafety Index'. The increase of the standardized value of each index may suggest the declining of the situation, and the decrease of the standardize value may suggest the improving of the situation.

$$
\begin{aligned}
& S\left(D_{i}\right)=\left\{\begin{array}{lc}
\frac{X_{i}}{Y_{i}} & \left(X_{i} \leq Y_{i}\right) \\
1 & \left(X_{i}>Y_{i}\right)
\end{array}\right. \\
& S\left(D_{i}\right)=\left\{\begin{array}{lc}
1-\frac{X_{i}}{Y_{i}} & \left(X_{i} \leq Y_{i}\right) \\
0 & \left(X_{i}>Y_{i}\right)
\end{array}\right.
\end{aligned}
$$

In which, the is the standardized value of the initial value (), while is the threshold value of the index.

The determination of threshold value for the basic evaluation index is a key requirement for the data standardization. Local standards and local investigations are used as the reference to determine the threshold value of each basic index of the four-layer evaluation index system to assess ecological security of Baiquan county with soil and water loss stress. The results and their references are listed in Table 2.

\section{Results and discussion}

\section{Assessment results}

Figure 1 depicts the variations of 'Pressure' $\left(B_{1}\right)$ subindex, 'Status' $\left(B_{2}\right)$ sub-index, 'Response' $\left(B_{3}\right)$ sub-index and the topmost 'Ecological Unsafety Index' $\left(A_{1}\right)$ of Baiquan county during from 1979 to 2005 . The calculated values of $A_{1}$ decreased about $37.9 \%$, from 0.701 to 0.435 , during the period of 1979 2005, which suggests the ecological situations of Baiquan county are improving during these years.

However, the 'Pressure' sub-index $\left(B_{1}\right)$ does not change a lot during the four years of 1979, 1990, 2000 and 2005. In these four years, the highest value of 'Pressure' sub-index is 0.142 and the lowest value of 'Pressure' value is 0.133 . This is mainly due to the mutually counter-balance of the sub-indices of 'Pressure' index. For example, the 'Fertilizer Load' $\left(D_{5}\right)$ and 'Pesticide Load' $\left(D_{6}\right)$ increased greatly since 1979 due to the unreasonable actions of the local farmers (Figure 2a). While, the standardized values of Area Proportion of Soil and water Loss $\left(D_{4}\right)$ decreased a lot due to the demonstration actions of soil and water control in 
Table 2 Threshold values for the basic index of the evaluation indices

\begin{tabular}{|c|c|c|c|}
\hline Basic Index & $\begin{array}{l}\mathrm{P} / \\
\mathrm{N}^{*}\end{array}$ & $\begin{array}{l}\text { Threshold } \\
\text { Value }\end{array}$ & References \\
\hline Natural Population Growth Rate $\left(D_{1}\right)$ & $\mathrm{P}$ & $8 \%$ & Wang, 2005 [13] \\
\hline Population Density $\left(D_{2}\right)$ & $P$ & $\begin{array}{c}81.4 \text { person/ } \\
\mathrm{hm}^{2}\end{array}$ & Average value of Heilongjiang province, 2005 \\
\hline Per Capita Arable Land $\left(D_{3}\right)$ & $P$ & $\begin{array}{l}0.43 \mathrm{hm}^{2} / \\
\text { person }\end{array}$ & Eco-construction Primary Standard of Heilongjiang Province \\
\hline Area Proportion of Soil and water Loss $\left(D_{4}\right)$ & P & $27.2 \%$ & Target of the starting stage of eco-construction of Heilongjiang province \\
\hline Fertilizer Load $\left(D_{5}\right)$ & $P$ & $200 \mathrm{~kg} / \mathrm{hm}^{2}$ & $\begin{array}{c}\text { Construction standards of ecological demonstration areas in Heilongjiang } \\
\text { province }\end{array}$ \\
\hline Pesticide Load $\left(D_{6}\right)$ & $P$ & $4.2 \mathrm{~kg} / \mathrm{hm}^{2}$ & Average value of Heilongjiang province, 2005 \\
\hline Probability of Natural Disaster $\left(D_{7}\right)$ & $\mathrm{P}$ & $41.5 \%$ & Average value of Heilongjiang province, 2005 \\
\hline Forestry and Grass Coverage $\left(D_{8}\right)$ & $\mathrm{N}$ & $25 \%$ & $\begin{array}{c}\text { Construction standards of ecological demonstration areas in Heilongjiang } \\
\text { province }\end{array}$ \\
\hline Soil Erosion Modulus $\left(D_{9}\right)$ & $\mathrm{P}$ & $2500 \mathrm{t} / \mathrm{km}^{2} \mathrm{a}$ & Soil erosion classification standard \\
\hline Effective Thickness of Soil Layer $\left(D_{10}\right)$ & $P$ & $20 \mathrm{~cm}$ & Zhang et al., 2006 [14] \\
\hline $\begin{array}{c}\text { Precipitation Rate of April May to } \\
\text { July August }\left(D_{11}\right)\end{array}$ & $P$ & 39.3/337.7 & Achieved from the analysis of the historical statistical data \\
\hline Effective Irrigation Rate of Arable Land $\left(D_{12}\right)$ & P & $30 \mathrm{~mm}$ & Shu K L, 2006 [15] \\
\hline $\begin{array}{c}\text { Agricultural Technican Per Ten Thousand } \\
\text { People }\left(D_{13}\right)\end{array}$ & $P$ & 4 person & China rural well-off social standards \\
\hline $\begin{array}{l}\text { Area Proportion of Soil and Water Loss } \\
\text { Control }\left(D_{14}\right)\end{array}$ & N & $50 \%$ & $\begin{array}{l}\text { Construction standards of ecological demonstration areas in Heilongjiang } \\
\text { province }\end{array}$ \\
\hline Per Capita Rural Net Income $\left(D_{15}\right)$ & $\mathrm{N}$ & $2000 \mathrm{RMB}$ & $\begin{array}{l}\text { Construction standards of ecological demonstration areas in Heilongjiang } \\
\text { province }\end{array}$ \\
\hline $\begin{array}{l}\text { Agriculture Production Per Unit Cultivated } \\
\text { Land }\left(D_{16}\right)\end{array}$ & $\mathrm{N}$ & $\begin{array}{l}10000 \mathrm{RMB} / \\
\mathrm{hm}^{2}\end{array}$ & $\begin{array}{c}\text { Construction standards of circular economy demonstration areas in } \\
\text { Heilongjiang province }\end{array}$ \\
\hline
\end{tabular}

${ }^{*}$ p-positive indicator; N-negative indicator.

Baiquan County (Figure 2a). And it is noticeable that the four year's standardized values of the Population Density $\left(D_{2}\right)$ are beyond the threshold values, which implies that the growth of the population has put high pressure to the ecological situation of Baiquan County.

The calculated value of 'Status' $\left(B_{2}\right)$ sub-index is 0.380 in 1979 , and it decreased about $40 \%$ during the period

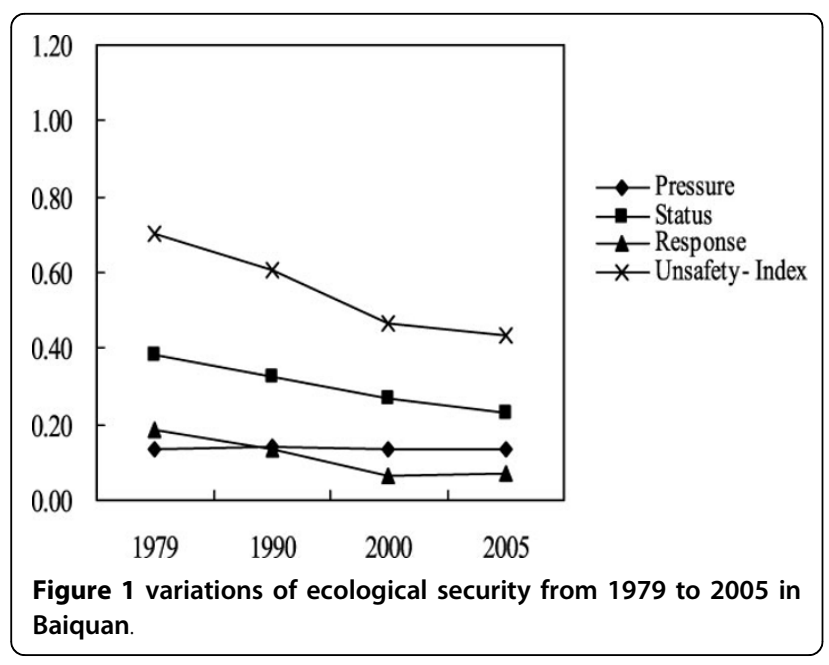

of 1979 2005 (Figure 1). In 2005, the calculated value of $B_{2}$ is 0.228 . The declining of 'Status' $\left(B_{2}\right)$ sub-index indicates that the ecological status of Baiquan County is improving from 1979 to 2005. Even so, not all the aspects of the ecological status are improving. As shown in Figure 2b, the standardized values of 'Effective Thickness of Soil Layer' $\left(D_{10}\right)$ increased during the years of 1979 2005. The effective thickness of black soil could affect the soil productivity directly, which has important influences on the food production and regional ecological security subsequently. It is also noticeable that the standardized values of 'Probability of Natural Disaster' $\left(D_{7}\right)$ for four years are beyond the threshold values, which implies great threat to the ecological status of Baiquan county.

The calculated values of 'Response' $\left(B_{3}\right)$ decreased from 1979 to 2000 and then increased a bit in 2005 (Figure 1). The increase of standardized values of the 'Per Capita Rural Net Income' $\left(D_{15}\right)$ and the 'Agriculture Production Per unit Cultivated Land' $\left(D_{16}\right)$ in 2005 may result in the increase of the calculated values of $B_{3}$ in 2005 (Figure 2c). Therefore, the net income of rural people and the production of the cultivated land in Baiquan county should be improved to decrease the unsafety level of the 'Response' 


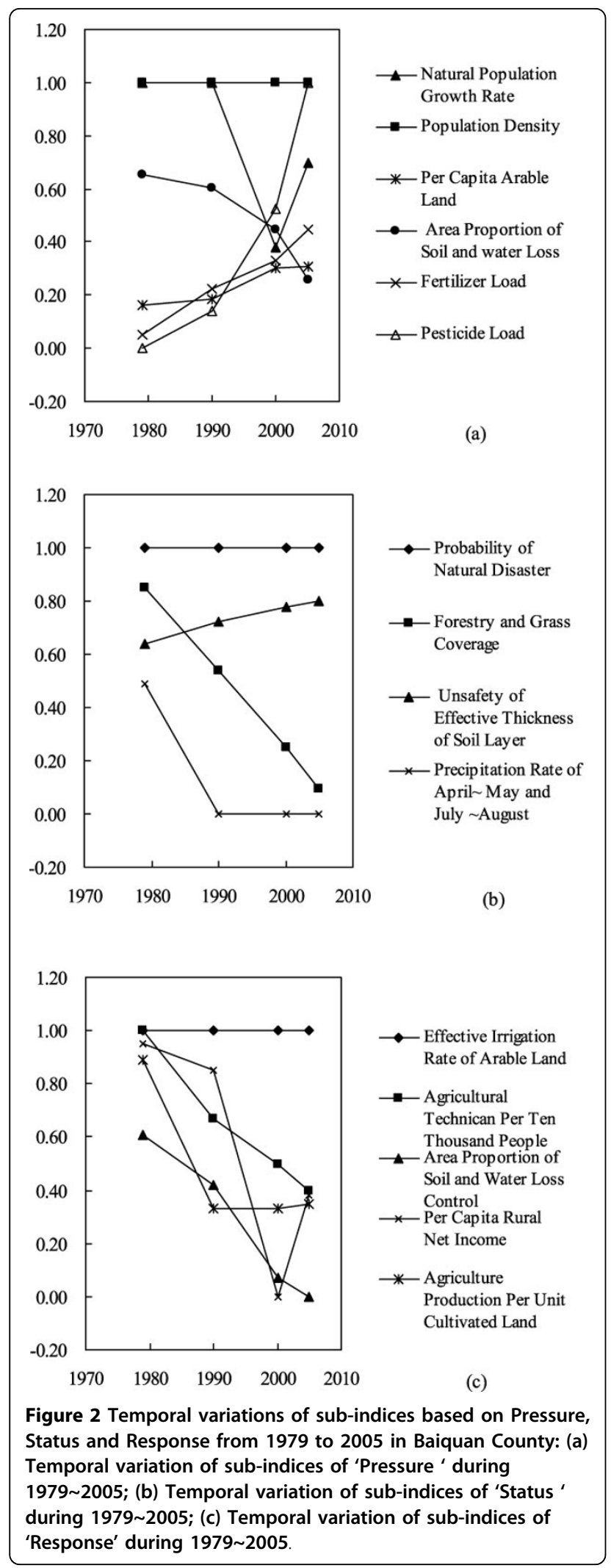

sub-index. It is also noticeable that the standardized values of 'Effective Irrigation Rate of Arable Land' $\left(D_{12}\right)$ for four years are beyond the threshold values (Figure 2c), which may imply the high vulnerability of Baiquan County to the stress of natural disasters.

\section{Discussion}

\section{Potential problems to the ecological security}

Through the analysis of the assessment results, several potential problems are found to be great threat to the ecological security of Baiquan County.

Firstly, although the areas of soil and water loss control are increasing every year, the effective thickness of black soil is still decreasing. The food productivity of the parent material of the black soil is very low. The current average thickness of black soil is about $25 \mathrm{~cm}$ in Baiquan County. When the thickness of black soil is lower than $20 \mathrm{~cm}$, the soil productivity would decrease sharply and lower the food production [16]. This would be potential risk to the food security and should be further investigated in the future.

Secondly, the application of the fertilizer is increasing with the year due to the loss of the black soil and the decrease of the productivity of the black soil in Baiquan County. The excessive application of the fertilizer has resulted in the aggravation of soil and water environmental pollution. How to adjust the fertilizer policies to reduce the application amount of the fertilizer is important to improve the environmental quality.

Thirdly, the low efficiency of the agricultural irrigation system in Baiquan County has brought high vulnerability to the draught disasters, which is frequently happened in the spring of the local areas. Therefore, the calculated values of 'Effective Irrigation Rate of Arable Land' $\left(D_{12}\right)$ and 'Probability of Natural Disaster' $\left(D_{7}\right)$ for four years are beyond the threshold values. Efficient countermeasures should be taken to improve the agricultural irrigation system in Baiquan County.

\section{Effects of soil and water control on the ecological security}

The soil and water control curse in Baiquan County could be divided into two stages. Before 1986, the soil and water control actions are scattered in small scales. The analysis of the historical data implies the failure of the scattered control actions during this period. For example, in the end of 1970 s, the forest coverage was even under $3.7 \%$ with various natural disasters [16]. Poverty was exacerbated with the deterioration of the ecological system in that period in Baiquan County. The Baiquan county government has changed soil and water loss control polices since 1986. Comprehensive demonstration actions are taken in large scales. The area proportion of soil and water control is 
increased with the year. Based on the theory of ecology, comprehensive countermeasures not only bring ecological benefits but also bring economic benefits to the local areas. Thus the comprehensive soil and water loss control demonstration actions have made great contribution to improvement of the ecological status.

\section{Conclusions}

Based on the pressure-state-response (P-S-R) framework model, the comprehensive evaluation method was proposed to investigate on the temporal variations of ecological security with Soil and Water Loss Stress in Baiquan County. The calculated values of the 'Ecological Unsafety Index' decreased from 0.701 to 0.435 during the period of 1979 to 2005. In general, the ecological security situations of Baiquan County are improving during these years. However, several problems are recognized to be the potential threats to the ecological security in the local areas. The reduction of the effective thickness of the black soil is found to be one of the potential risks to the food security of Baiquan County. The excessive application of the fertilizer has resulted in the aggravation of the soil and water environmental pollution, and how to adjust the fertilizer structure to reduce the application amount of the fertilizer is important to improve the environmental quality. The low efficiency of the agricultural irrigation system has increased the vulnerability of Baiquan County to the draught disasters, and efficient countermeasures are suggested to be taken. Through the investigation on the ecological security and its relationship with soil and water control curse, it is found that comprehensive soil and water loss control demonstration actions have made great contribution to the improvement of the ecological security.

\section{Competing interests}

The authors declare that they have no competing interests.

\section{Acknowledgements \\ Financial support is from National Natural Science Foundation of China (Grant No. 41001165;41271305).}

\section{Declarations}

The publication costs for this article were funded by Scientific \& Technical Development Inc.

This article has been published as part of SpringerPlus Volume 2 Supplement 1, 2013: Proceedings of the 2010 International Conference on Combating Land Degradation in Agricultural Areas (ICCLD'10). The full contents of the supplement are available online at http://www.springerplus.com/ supplements/2/S1.

\section{Authors' details}

'Key Laboratory of Water Cycle and Related Surface Processes, Institute of Geographical Sciences and Resources Research, Chinese Academy of Sciences, Beijing 100101, China. ${ }^{2}$ Guangxi Hydraulic Research Institute, Nanning 530023, China.

Published: 11 December 2013
References

1. Ezeonu IC, Ezeonu FC: The environment and global security. The Environmentalist 2000, 20(1):41-48.

2. Dobson AP, Bradshaw AD, Baker AJM: Hopes for the future: Restoration ecology and conservation biology. Science 1997, 277(5325):515-522.

3. Zhao $Y Z, Z$ Zou $X Y$, Cheng $H$, et al: Assessing the ecological security of the Tibetan Plateau: Methodology and a case study for Lhaze County. Journal of Environmental Management 2006, 80(2):120-131.

4. Rapport DJ, Gaudet C, Karr JR, et al: Evaluating landscape health: integrating social goals and biophysical process. Journal of Environmental Management 1998, 53(1):1-15.

5. Yu KJ: Security patterns and surface model in landscape ecological planning. Landscape and Urban Planning 1996, 36(1):1-17.

6. Huang $\mathrm{Q}$, Wang $\mathrm{RH}$, Ren $\mathrm{ZY}$, et al: Regional ecological security assessment based on long periods of ecological footprint analysis. Resources, Conservation and Recycling 2007, 51(1):24-41.

7. Gong JZ, liu YS, Xia BC, et al: Urban ecological security assessment and forecasting, based on a cellular automata model: A case study of Guangzhou, China. Ecological Modelling 2009, 220(24):3612-3620.

8. Li YF, Sun $X$, Zhu XD, et al: An early warning method of landscape ecological security in rapid urbanizing coastal areas and its application in Xiamen, China. Ecological Modelling, Article in press 2010.

9. Zhang YG, Wu YQ, Liu BY, et al: Characteristics and factors controlling the development of ephemeral gullies in cultivated catchments of black soil region, Northeast China. Soil \& Tillage Research 2007, 96(1-2):28-41.

10. Fang HJ, Yang XM, Zhang XP, et al: Using 137 Cs Tracer Technique to Evaluate Erosion and Deposition of Black Soil in Northeast China. Pedosphere 2006, 16(2):201-209.

11. Sun $L Y, N i J R$, Borthwick $A G L$ : Rapid assessment of sustainability in mainland China. Journal of Environmental Management 2010, 91(4):1021-1031.

12. Belton $V$, Goodwin P: Remarks on the application of the analytic hierarchy process to judgmental forecasting. International Journal of Forecasting 1996, 12(1):155-161.

13. Wang LG: Study on the ecological safety - in the case of Jianghan Plain. Master's degree thesis. Wuhan: Huazhong Normal University, China 2005, in Chinese.

14. Zhang XY, Liu XB, Sui YN, et al: Effects of artificial topsoil removal on soybean dry matter accumulation and yield in black soil area. Soybean Science 2006, 25(2):123-126, (in Chinese).

15. Shu KL: Theory and Empirical Study on assessment of ecological safety in Jilin province, Master's Degree Thesis, Changchun: Jilin University. 2006, in Chinese.

16. Northeast Institute of Geography and Agroecology, Chinese Academy of Sciences, et al: Comprehensive scientific investigation on soil erosion and ecological security in China-investigation report on black soil region of Northeast China (rough draft). 2006, in Chinese.

doi:10.1186/2193-1801-2-S1-S6

Cite this article as: Sun et al:: Temporal variations of ecological security with soil and water loss stress in black soil region of northeast China: a case study on Baiquan County. SpringerPlus 2013 2(Suppl 1):S6.

\section{Submit your manuscript to a SpringerOpen ${ }^{\odot}$ journal and benefit from:}

- Convenient online submission

- Rigorous peer review

- Immediate publication on acceptance

- Open access: articles freely available online

- High visibility within the field

- Retaining the copyright to your article

Submit your next manuscript at $>$ springeropen.com 